\title{
O SÍNODO DA AMAZÔNIA - UM ACONTECIMENTO DEFINIDOR
}

\section{The Amazon Synod - a defining event}

Joviniano S. de Carvalho Neto

(CEAS/UFBA)

Lattes Id http://lattes.cnpq.br/2255490272129974

Informações do artigo

Recebido em 01/04/2020

Aceito em 29/04/2020

doi>: https://doi.org/10.25247/2447-861X.2020.n249.p33-62

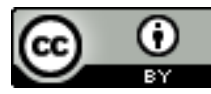

Esta obra está licenciada com uma Licença Creative Commons Atribuição 4.0 Internacional.

Como ser citado (modelo ABNT)

CARVALHO NETO, Joviniano S. de. O Sínodo da Amazonas - um acontecimento definidor. Cadernos do CEAS: Revista Crítica de Humanidades. Salvador, $\mathrm{n}$. 249, jan./abr., p. 33-62, 2020. DOI: https://doi.org/10.25247/2447-861X.2020.n249.p33-62

\begin{abstract}
Resumo
O artigo analisa o Sínodo da Amazônia, promovido pela Igreja Católica, em Roma, de 6 a 27 de outubro de 2019. Contém apresentação do significado e relevância; análise em 3 partes: o projeto da Igreja para o Sínodo, a cobertura da mídia impressa, e a posição final do Papa; a conclusão, que inclui o Sínodo na política proposta pelo Papa Francisco de novo modelo civilizatório e conversão da própria Igreja.

Palavras-chave: Sínodo da Amazônia. Papa Francisco. Igreja Católica. Questão ambiental.
\end{abstract}

\section{Abstract}

The article analyzes the Amazon Synod, promoted by the Catholic Church, in Rome, from October 6 to 27, 2019. It contains a presentation of the meaning and relevance; 3 part analysis: the Church's project for the Synod, the coverage of the print media, and the Pope's final position; the conclusion that includes the Synod in the politics proposed by the Pope Francis of a new civilizing model and conversion of the Church itself.

Keywords: Synod of the Amazon. Pope Francis. Catholic church. Environmental issue.

\section{Significado e relevância}

O Sínodo da Amazônia, realizado em Roma, de 6 a 27 de outubro de 2019, foi a ação mais expressiva, em termos políticos e eclesiais, do Papa Francisco e da Igreja Católica, em 2019. Resultante de um longo percurso, representou a convergência e integração, na política da lgreja, de três movimentos de caráter planetário.

O primeiro, de defesa do meio ambiente, da nossa "casa comum". Ameaçada por um modelo de crescimento baseado na exploração sem limites e em uma cultura de descarte (inclusive de pessoas), que está na raiz da crise socioambiental, da qual as mudanças climáticas são uma expressão da ameaça à sustentabilidade do planeta.

O segundo, a percepção do papel da Amazônia para o equilíbrio ambiental, inclusive do clima, ameaçado pela ocupação e devastação. 
O terceiro, o processo de valorização da cultura e terras dos povos tradicionais, inclusive indígenas ameaçadas, que é associado à percepção de sua importância para a manutenção da biodiversidade.

Diante destes movimentos, a Igreja Católica assumiu a busca de:

a) Construção de uma alternativa planetária, do que poderíamos chamar de novo paradigma civilizatório;

b) Uma inculturação ${ }^{1}$, da qual resulte uma Igreja com face amazônica.

No momento em que este sínodo foi realizado, contribuíram para a sua relevância política, inclusive no Brasil, 3 fatores:

a) A repercussão internacional da ampliação das queimadas na Amazônia e do posicionamento do governo federal brasileiro;

b) A proximidade da Conferência do Clima da ONU (COP 25), que se realizaria em MADRID (2 a 13/12/2019), para discutir o desenvolvimento do Acordo de Paris (2015), no qual previam-se posições negacionistas do governo Norte Americano (Trump) e desviantes ou defensivas do governo brasileiro (Bolsonaro);

c) As mudanças possíveis no funcionamento, disciplina e liturgia da Igreja Católica, contra as quais reagem os conservadores e tradicionalistas, que se opõem ao Papa Francisco.

Estes fatos justificam uma atenção especial sobre o sínodo, objeto deste artigo.

O trabalho divide-se em três partes: na primeira, procuramos reconstituir o projeto da Igreja, com informações retiradas de publicações dela oriundas e observações nossas;na segunda, fazemos uma breve apresentação de como o evento foi apresentado pela mídia impressa; e na terceira, elaboramos, após o Papa lançar a Exortação Apostólica (cerca de três meses depois do sínodo), um resumo que, se não reconstitui a riqueza do texto, apresenta o conteúdo das posições defendidas.

\footnotetext{
1 Companhia de Jesus. $32^{\text {a }}$ Congregação Geral da Companhia de Jesus, Decreto 5, Nossa Missão Hoje: Serviço da Fé e Promoção da Justiça, n. 2, Lisboa, 1975. Conforme o Pe. Pedro Arrupe inculturação é a encarnação da vida e das mensagens cristãs em uma área cultural concreta de modo que não somente esta experiência se exprima com elementos da cultura em questão (o que ainda não seria senão uma adaptação), mas que esta mesma experiência se transforme em princípio de inspiração, ao mesmo tempo norma e força de unificação que transforma e recrie esta cultura, encontrando-se, assim, na origem de uma nova criação.
} 


\section{O projeto da Igreja}

\section{A convocação}

A convocação do Sínodo da Amazônia, sua natureza e objetivos se inserem em um processo histórico de evolução da Igreja Católica e da linha que se procura implantar no papado de Francisco. Sobre a gênese imediata do sínodo, um testemunho essencial é o do Cardeal D. Cláudio Hummes2. Íntimo do Papa Francisco - sua frase "não se esqueça dos pobres" - quando da sua eleição, o teria inspirado a adotar o nome Francisco3; participou de eventos que antecederam a convocação do Sínodo, assistiu a sua convocação e coordenou a REPAM - Rede Eclesial Pan Amazônica que, criada em setembro de 2014, que foi incumbida de ajudar, animar e promover a preparação do Sínodo no Território Pan Amazônico; foi designado, como o relator geral do Sínodo. O pequeno livro, lançado pelo idoso, ativo e progressista cardeal4, em 2019, para divulgar e expor o processo sinodal e sua temática é base em que muito nos apoiaremos e que nos provocou reflexões e complementações.

Hummes começa o livro com a convocação do sínodo: "Aconteceu no dia 15 de outubro de 2017, na Praça de São Pedro, em Roma. O Papa Francisco havia terminado a solene missa de canonização dos protomártires brasileiros de Cunhaú e Uruaçu, bem como de dois adolescentes indígenas mexicanos mártires. "Eu tive a graça de estar ali na Praça concelebrando a Missa". "Na noite anterior, o Papa me havia dito: amanhã vou anunciar o Sínodo Especial para a Amazônia"5.

A presença de D. Cláudio, o coordenador da REPAM, na Missa, não foi, assim, acidental. Uma observação nossa. O anúncio do Sínodo chamou mais a atenção, inclusive no Brasil, do que a canonização. Este tinha, em país com poucos santos reconhecidos, um

2 HUMMES, Claudio. O Sínodo para a Amazônia. Cardeal D. Claudio Hummes. São Paulo: Paulus, 2019, 95 p. (coleção Comunidade e Missões).

3 ALTERMEYER Jr. Fernando. Os muitos partos do bispo de Roma. In. PASSOS, João Décio; SOARES, Afonso M. L. (Orgs.). Francisco: renasce a esperança. São Paulo, Paulinas, 2013. p. 106.

4 Nascido em 1934, o cardeal já completou 85 anos. Da Ordem Franciscana dos Frades Menores, foi Bispo de S. André, Cidade Operária de São Paulo, de 1975 (acompanhou 10 anos da Ditadura Militar e a reativação do movimento operário) a 1986, quando passou a Arcebispo de Fortaleza (1996 a 1998) e de São Paulo (19982010) quando Bento XVII aceitou sua renuncia por idade. Enquanto Arcebispo de São Paulo, segundo a tradição, o Papa João Paulo Il o nomeou Cardeal. A partir de 2011, e quando do lançamento do livro, exercia a função de Vigário Geral da Arquidiocese de São Paulo, acompanhando pastorais sociais. A idade não o impediu de, pela REPAM, fazer visitas pastorais a 38 dioceses e prelazias da Amazônia.

5 Hummes, op. Cit. p. og. 
significado que vale relembrar, sem anacronismo, mesmo em tempo de ecumenismo e diálogo inter-religioso. Os santos de Cunhaú e Uruaçu morreram dando testemunho da sua fé. Em 1645, durante a ocupação dos holandeses (protestantes ou huguenotes), foram massacrados, católicos que permaneceram fiéis a sua fé. Seu martírio foi lembrado e cultuado, especialmente no Rio Grande do Norte, até o presente6. A sua canonização, a nosso ver, combina com uma política voltada para a evangelização dos indígenas, ainda que com novos métodos. Esta observação sintoniza com a fala do Papa, transcrita por Hummes:

Acolhendo o desejo de algumas Conferências Episcopais da América Latina, assim como a voz de diversos pastores e fiéis de outras partes do mundo, decidi convocar uma Assembleia Especial do Sínodo dos Bispos para a região Pan-Amazônica, que terá lugar em Roma no mês de outubro de 2019. A finalidade principal dessa convocação é encontrar novos caminhos para a evangelização daquela porção de Povo de Deus, sobretudo dos indígenas, muitas vezes esquecidos e sem perspectivas de um futuro sereno, também por causa da crise da Floresta Amazônica, pulmão de importância fundamental para o nosso planeta7.

\section{O Sínodo para uma Região}

Hummes assinala que o sínodo teria características inovadoras - abarcaria somente uma parte geográfica de vários países envolvidos e não o todo e, pela primeira vez, os indígenas e a ecologia seriam temas centrais. Apresenta, sumariamente, a região "seu território é compartilhado por 9 países - em termos arredondados $67 \%$ pertence ao Brasil, $13 \%$ ao Peru, $11 \%$ a Bolívia, $6 \%$ a Colômbia, $2 \%$ ao Equador e 1,1\% a Venezuela, Suriname, Guiana e Guiana Francesa. O território tem 7,8 milhões de km2 [...] e conta com 34 milhões de habitantes, dos quais cerca de 3 milhões são indígenas, 390 povos (137 isolados) 240 línguas de 49 famílias linguísticas. Uma imensa riqueza cultural, histórica, religiosa e étnica,

6 Os massacres ocorreram a 16 de julho, em Cunhaú, Capela de Nossa Senhora das Candeias, Engenho de Cunhaú, Canguaretana e 3 de outubro em Uruaçu, comunidade do município de São Gonçalo do Amarante. Em ambos os casos, os fiéis foram mortos durante a missa (línguas arrancadas, braços e pernas cortados, crianças degoladas e partidas ao meio, coração de camponês arrancado). Foram mortas mais de 80 pessoas, denominadas como protomártires do Brasil. O ataque foi conduzido por alemão a serviço dos holandeses. $O$ martírio é elemento marcante da cultura religiosa do RGN desde então. O processo foi aberto em 16 ago. 1989, a beatificação (2 padres e 28 leigos) foi em 05 mar. 2005 e a santificação ocorreu sob o Papa Francisco. Em 05 dez. 2005 foi inaugurado Monumento dos Mártires (Mun. de São Gonçalo do Amarante) com capacidade para 20 mil peregrinos. O "dia dos mártires" é feriado estadual (Lei 8931/2006).

7 HUMMES, Op. cit., p. og. 
hoje mais do que nunca ameaçada" ${ }^{8}$. Para complementar esta visão da região, antecipamos algumas informações do documento oficial preparado em Roma, para o sínodo9:

a) "A bacia do Rio Amazonas e as florestas tropicais que a circundam [...] regulam os ciclos de água, energia e carbono a nível planetário". O Rio Amazonas lança, sozinho, todos os anos, no Oceano Atlântico, 15\% do total de água doce do planeta. A Amazônia é essencial para a distribuição de chuvas e movimento de ar no planeta, mas seria a $2^{\mathrm{a}}$ área (a primeira, o Ártico) mais vulnerável por mudanças climáticas decorrentes da ação humana.

b) "A floresta amazônica cobre aproximadamente 5,3 milhões de km, 40\% da área de florestas tropicais do globo. Os ecossistemas da Amazônia abrigariam cerca de 10 a $15 \%$ da biodiversidade terrestre, armazenando anualmente de 150 a 200 milhões de toneladas de carbono".

Complementando, lembramos que as diferentes dimensões dos países e das populações indígenas neles residentes resulta em impacto diferente em cada um deles. Comparando os dados fornecidos por HUMMES (dimensão da Amazônia e percentual dela por país) com o território dos mesmos, verifica-se que os $67 \%$ da Amazônia no Brasil correspondem a $61 \%$ do território. Os $13 \%$ no Peru representam $79 \%$, os $11 \%$ na Bolívia representam $78 \%$, os $6 \%$ na Colômbia, a $41 \%$, os $2 \%$ no Equador, a $55 \%$. Os 1,1\% da Amazônia no conjunto da Venezuela, Suriname, Guiana e Guiana Francesa correspondem a $6 \%{ }^{10}$.

É importante lembrar que o peso das populações indígenas na população e na política é muito mais evidente na Bolívia, Equador e Peru que no Brasil.

8 HUMMES, Op. cit. p. 10.

9 ASSEMBLEIA ESPECIAL DOS BISPOS. Amazônia, novos caminhos para a lgreja e uma ecologia integral Instrumentum Laboris. Para a Assembleia Especial do Sínodos dos Bispos para a região Pan-Americana. Brasília: edições CNBB, 2019, p. 89.

${ }^{10}$ Para os que desejam repetir o exercício, informamos que utilizamos as seguintes dimensões por país: BRASIL: $8.515 .767 \mathrm{~km} 2$; PERU: $1.285 .216 \mathrm{~km} 2$; BOLÍVIA: $1.098 .581 \mathrm{~km} 2$; COLÔMBIA: $1.138 .914 \mathrm{~km} 2$, EQUADOR: 283.561km2, VENEZUELA: $916.445 \mathrm{~km} 2$; SURINAME: $163.270 \mathrm{~km} 2$; GUIANA: 214.969km2; GUIANA FRANCESA: $889.150 \mathrm{~km} 2$. 
O percurso para o Sínodo

\section{Antecedentes imediatos}

Hummes fala que a decisão do Papa decorreu de um processo que, para ele, se iniciou em julho de 2013 (Francisco foi eleito em 13 de março), quando o Papa, substituindo

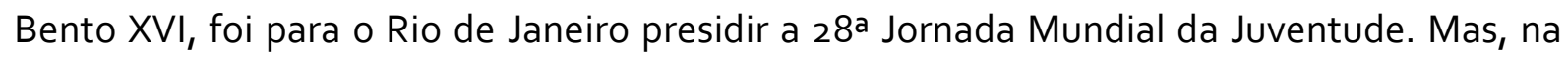

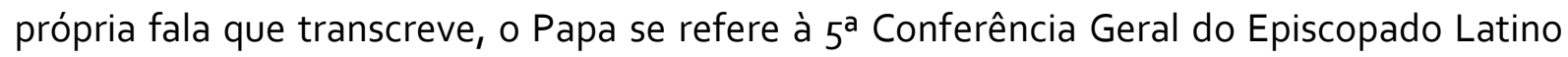
Americano e Caribenho, realizada em Aparecida, no Brasil, em 2007, na qual participara como Cardeal Arcebispo de Buenos Aires e, acrescentamos, foi um dos relatores do Documento final.

Na Conferência, Bento XVI, em discurso no Estádio do Pacaembu (São Paulo), denunciara a "devastação ambiental da Amazônia e as ameaças à dignidade de seus povos". O Documento final denunciou a exclusão das populações tradicionais, a agressão à natureza, o tratamento da água como mercadoria negociável pelas empresas e disputada pelas grandes potencias.

Em 2019, o Papa relembra a fala de Aparecida em defesa da criação e afirma a permanente presença da Igreja na região: "A Igreja está na Amazônia não como aqueles que tem as malas na mão para partir depois de terem explorado tudo o que puderam. Desde o início, a Igreja está presente na Amazônia $[. . .]^{11}$ e lá continua presente e determinante no futuro daquela área".

Ainda falando de antecedentes imediatos e com base em outro capítulo de Hummes, acrescentamos a publicação da "Encíclica Laudato SI", em março de 2015, dedicada à questão ambiental, na qual o Papa denuncia a crise socioambiental e o modelo que a gera. Hummes lembra que, após a Encíclica, em dezembro de 2015, ocorreu a COP 21 da qual resultou um amplo acordo climático.

\section{Antecedentes de médio e longo prazo}

Refletindo a evolução, no mundo e na Igreja Católica, da consciência ambientalista e das mudanças climáticas, da importância da Amazônia e da defesa da cultura e terras

\footnotetext{
${ }^{11}$ HUMMES, Op. cit. p. 16.
} 
indígenas, pode-se encontrar raízes mais antigas e profundas. Acresce que é característica dos documentos promulgados pelos Papas e pela Igreja Católica buscar sua legitimação nas citações dos predecessores e, inclusive, da Bíblia. Isto não mudou, e até, tratando-se de um Papa renovador, torna-se ainda mais importante. É parte da estratégia da Igreja mostrar que suas posições são resultado de um acúmulo histórico. Esta marca está muito presente, por exemplo, no "Instrumentum Laboris" preparado para o sínodo. Se alguma novidade existe, esta poderia ser a da busca de legitimação, também, nas informações científicas, aliás, decorrentes do método VER - JULGAR - AGIR, característico da Ação Católica ${ }^{12}$. Assim considerando, podemos nos referir às mudanças ocorridas, especialmente a partir do fim dos anos 60 e da década de 1970. Isto remete ao Concílio Vaticano II (1963-1965), que o Papa Francisco reativa e, no mundo, à emersão do movimento ambientalista, que teve como marco o documento apresentado na Assembleia Geral da ONU, em $1987^{13}$, e a experiência da Igreja brasileira no enfrentamento da Ditadura Militar.

Falando da evolução da posição da Igreja Católica sobre Amazônia, questões indígena e ambiental, partimos do quadro definido pela II Guerra Mundial (1939-1945) como se expressava nos fins dos anos 60 e na década de 1970. Da II Guerra Mundial resultou, de um lado, o avanço no reconhecimento dos Direitos Humanos, dos povos e das minorias; do pluralismo político e do sentimento ecumênico. De outro, levou à polarização entre o "Ocidente", apresentado como cristão, mas capitalista liderado pelos USA, e o "Oriente", apresentado como comunista e ateu, liderado pelo URSS.

O golpe ("Revolução" para os militares) de 1964 alegou a defesa da democracia e da civilização ocidental e cristã contra a corrupção e a subversão ${ }^{14}$.

A ditadura militar implantou, no Brasil, uma modernização capitalista autoritária que, nas cidades, levou ao crescimento da economia, mudou a estrutura industrial e a

\footnotetext{
${ }^{12}$ A aplicação do método Ver - Julgar - Agir significa partir da realidade para julgá-la a partir de critérios evangélicos e não partir da revelação divina e julgar a conformidade da realidade com ela.

13 COMISSÃO MUNDIAL SOBRE O MEIO AMBIENTE E DESENVOLVIMENTO. Nosso Futuro Comum. Rio de Janeiro: Fundação Getúlio Vargas, 1988, 430 p. O livro apresenta relatório solicitado pela Assembleia Geral das Nações Unidas e a ela apresentado em 1987. Os trabalhos iniciaram em 1983 e, a nosso ver, conclui polêmica iniciada na década de 70, pelo Clube de Roma. Cf, MEADOWS, D. L. et. al. Limites do crescimento um relatório para o projeto do Clube de Roma sobre o dilema da humanidade. São Paulo, Perspectivas, 1972.

${ }_{14}$ Para uma visão mais detalhada do quadro que as Igrejas enfrentavam no período, vide: CARVALHO NETO, Joviniano Soares de. Igrejas e Ditadura Militar na Bahia. Salvador, SAGGA, 2018, 196 p.
} 
composição da classe operária, implantou a rede nacional de comunicação e aumentou a urbanização com o crescimento das periferias.

No campo ocorreu um traumático choque com a expansão do capitalismo. O golpe de 1964 [...] editou o Estatuto da Terra, investiu na modernização, apoiando a agricultura voltada para a exportação, o uso de novos equipamentos, a implantação de empresas e sua expansão sobre terras, antes ocupadas por pequenos agricultores, posseiros e índios. Ampliaramse os conflitos [...] especialmente na Amazônia, defendida como área de expansão que os militares diziam querer "integrar para não entregar." 15

No Brasil, este projeto de fechamento político e imposição do projeto capitalista choca-se com o movimento de abertura para o social e a defesa dos direitos humanos impulsionado pelo Concílio Vaticano II, mas presente, também, entre setores evangélicos ${ }^{16}$. Símbolo desta contradição, o ano de 1968 foi o ano no qual os bispos latino americanos, em Medellín, assumiram a opção preferencial pelos pobres e, no Brasil, os militares editaram o Al-5 (1968-1979), expressão maior da ditadura, que abre os "Anos de Chumbo" (1968-1973), nos quais a repressão foi mais feroz.

É exatamente nestes anos que surgem as personalidades e instituições que serão as maiores referências, até o presente, da defesa dos índios, dos posseiros e da Amazônia. Marcam o encontro entre Dom Pedro Casaldáliga, Dom Tomás Balduíno e o CEAS - Centro de Estudos e Ação Social ${ }^{17}$.

Dom Pedro chegou, em 1968, a São Félix do Araguaia, no Mato Grosso, onde encontrou miséria, trabalho escravo, perseguições e expulsão de posseiros e uma mudança na relação entre Igreja e índios, promovida por D. Tomás Balduíno (bispo de Goiás) e pelas "Irmãzinhas de Jesus" junto aos Tapirapés, baseada na inculturação e no respeito às crenças indígenas.

O lançamento, no dia de sua posse como bispo (23/01/1971), do documento "Uma Igreja da Amazônia em conflitos com o latifúndio e a marginalização social" teve repercussão internacional e é marco na caminhada, dele e de Dom Tomás, que, com o apoio

\footnotetext{
${ }^{15}$ CARVALHO NETO, Joviniano Soares de. Op. Cit., p. 38. As concepções errôneas de que índios deveriam "evoluir" para se transformarem em brasileiros e a tese "nacionalista" da ameaça à soberania nacional expressa naquele tempo, está presente em falas no governo Bolsonaro.

${ }^{16}$ Expresso, por exemplo, pela criação do Conselho Mundial das Igrejas - CMI, em 1948.

${ }^{17}$ Ao referir ao papel do CEAS na Ditadura Militar, não estamos sendo autorreferentes (somos membros do CEAS desde 1968). O SNI referiu-se ao CEAS como principal órgão clerical progressista do Nordeste e o acompanhou sistematicamente. A revista "Cadernos do CEAS" circulava em todo o Brasil e até no exterior e forneceu importantes depoimentos e estudos.
} 
dos setores progressistas, resultou, em 1972, na criação do CIMI - Conselho Indigenista Missionário; em 1973, no lançamento do poema "I Juca Pirama aquele que deve morrer" e no desencadeamento do processo do qual resultaria, em 1975, a criação da CPT - Comissão Pastoral da Terra, por muitos anos presidida por Dom Tomás ${ }^{18}$. Em 1979, na Catedral de São Paulo, foi celebrada a "Missa da Terra sem Males", para nós, símbolo maior da inculturação ${ }^{19}$.

A história continuou após o fim da Ditadura Militar, porque os interesses da exploração predatória continuam. A CPP e a CIMI continuam apoiando trabalhadores rurais e índios, e denunciando as violências contra eles.

Padre Cláudio Perani (1932-2008), liderança maior do CEAS na época da ditadura, transferiu-se para a Amazônia, ajudou a implantar o sistema de defesa de direitos humanos e, em 1998, a Equipe Itinerante, antecessora, parteira e hoje parte da REPAM - Rede Eclesial Pan Amazônia, que preparou o Sínodo da Amazônia.

A presença da Amazônia, questões indígenas e ecológicas nas várias Campanhas da Fraternidade mostra que entraram na pauta da Igreja Católica. Fruto de longa caminhada, a deflagração específica do Sínodo ocorre em 2018.

A deflagração da preparação do Sínodo

Em 19 de janeiro de 2018, o Papa se encontra com os povos indígenas da Amazônia em Puerto Maldonado, no Peru, e declarou "Hoje, aqui se inicia o sínodo para a Amazônia". A REPAM, solicitada pelo Papa para ajudar a Secretaria Geral do Sínodo dos Bispos, havia realizado, na véspera, longo encontro com os indígenas. Compareceram mais de dois mil indígenas de toda a Amazonas, principalmente da Amazônia peruana.

\footnotetext{
${ }^{18}$ Articulado com Dom Pedro e Dom Tomás, o CEAS publicou Cadernos (25 e 26) com denúncias de Dom Pedro e D. Tomás sobre a repressão, em São Félix do Araguaia, documento "Marginalização de um povo" dos bispos do Centro Oeste no Cadernos 27 (apreendido pela Polícia Federal, inclusive por conter o documento dos bispos do Nordeste, "Eu ouvi os clamores do meu povo"), e em dezembro, um número especial dedicado a Amazônia (Cadernos 28), Dom Tomás reconheceu explicitamente a importância do CEAS na criação da CPT que assessorou durante anos a nível nacional e regional.

19 Para conhecer mais a história e o pensamento de Dom Pedro, ver os livros: CASALDÁLIGA, Pedro. Creio na justiça e na liberdade, Rio de Janeiro, Civilização Brasileira, 1976. TAVARES, Ana Helena. Um bispo contra todas as crenças. A vida e as causas de Pedro Casaldáliga. Rio de Janeiro, Gramma, 2019.
} 
O encontro do Papa com os indígenas ocorreu, de manhã, em grande estádio coberto (Coliseu Madre de Dios). O Papa sentou-se entre os chefe e sábios daqueles povos. Os indígenas falaram primeiro e o Papa discursou, afirmando sua solidariedade em defesa da vida, terra e cultura, propondo um diálogo intercultural onde os indígenas seriam os principais interlocutores, inclusive para a inculturação da Igreja nas suas culturas (uma Igreja com rosto amazônico, uma Igreja com rosto indígena) e anunciou que a primeira reunião do Conselho Pré-Sínodal se reuniria à tarde.

Na primeira reunião, o Conselho definiu o tema: "Amazônia: novos caminhos para a Igreja e para uma ecologia integral" e elaborou documento preparatório de consulta que deveria ser respondido até fevereiro de $2019 .{ }^{20} \mathrm{O}$ trabalho de consulta incluiu cerca de 87 mil pessoas.

No processo, foram oficialmente elaborados documentos preparatórios no Brasil, Colômbia, Bolívia, Venezuela e síntese pela REPAM. Paralelamente ocorreram seminários em Washington, USA, Roma e Bogotá. Peritos e representantes dos povos amazônicos participaram.

\section{Proposta para o Sínodo}

Para a apresentação da proposta da Igreja para o Sínodo, consideramos suficientes o livro de HUMMES, multicitado, e o documento oficial, "Instrumentum Laboris". No livro, HUMMES, além da apresentação da origem do Sínodo, apresenta mais 20 pequenos capítulos que, para tornar ainda mais claro o projeto, agrupamos em 3 eixos:

a) A crise climática e ecológica, que, sob a inspiração da "Laudato Si", exige um novo modelo de desenvolvimento ${ }^{21}$;

b) Os indígenas, seus problemas e o necessário protagonismo ${ }^{22}$;

${ }^{20}$ Estes parágrafos resumem o capitulo 2. O percurso sinodal. HUMMES, op. Cit., p. 13-16 com alguns acréscimos.

${ }^{21}$ Os cap. 3. A crise climática e ecológica (p. 17-19). 4: As causas da crise (p. 21-22); 5: As causas da crise II ( $p$. 25-27); 8: a importância de Laudato Si para o Sínodo (p. 37-39); 9: Ecologia Integral e Conversão Ecológica (p. 41-43); 20: Direito Universal a água (p. 85-87); 19: Novo modelo de desenvolvimento (p. 80-81).

${ }^{22}$ Cap. 06. Os povos indígenas da Amazônia (p. 29-31), cap. 07: As cidades amazônicas e o índio urbano (p. 3335). 
c) A inculturação e o relançamento da Igreja na Amazônia, parte que, significantemente, ocupara mais espaço no livro ${ }^{23}$.

O "Instrumentum Laboris" consta de três partes. A primeira, A VOZ DA AMAZÔNIA, visa apresentar a realidade do território e do seu povo, considera que a vida, que pode ser abundante, está ameaçada sobretudo:

a) pela criminalização e assassinato de líderes e defensores do território;

b) pela apropriação e privatização de bens da natureza, como a própria água;

c) por concessões à madeireiras legais e pela entrada de madeireiras ilegais;

d) pela caça e pesca predatórias, principalmente nos rios;

e) por megaprojetos: hidrelétricas, concessões florestais, desmatamento para produzir monoculturas, estradas e ferrovias, projetos mineiros e petroleiros;

f) pela contaminação ocasionada por todas as indústrias extrativistas que causam problemas e enfermidades, principalmente para as crianças e os jovens;

g) pelo narcotráfico;

h) pelos consequentes problemas sociais associados a tais ameaças, como o alcoolismo, a violência contra a mulher, o trabalho sexual, o tráfico de pessoas, a perda de sua cultura originária e de sua identidade (idioma, práticas espirituais e costumes) e todas as condições de pobreza às quais estão condenados os povos da Amazônia.

E que se deve defender o território, espaço geográfico e lugar teológico, belo e ameaçado onde tudo está interligado; valorizar o tempo, pois o sínodo seria um sinal dos tempos, de graça; inculturação e interculturalidade, desafios graves e urgentes, esperança; diálogo, cordial, histórico e escatológico, com relações políticas, culturais e ecológicas visando um pacto social para viver juntos, em uma sociedade justa, capaz de memória e

\footnotetext{
${ }^{23}$ Cap. 10: Uma Igreja inculturada na Amazônia (p. 45-47). Cap. 11: Uma Igreja indígena (p. 49-51); Cap. 12: Uma Igreja com rosto amazônico (p. 53-55); Cap. 13: O testemunho profético (p. 57-59); Cap. 14: Relançar a Igreja na Amazônia (p. 61-64); Cap. 15: Uma Igreja missionária (p. 65-67); Cap. 16: Eucaristia e ministros ordenados (p. 69-71); Cap. 17: Uma Igreja misericordiosa (73-75); Cap. 18: A opção preferencial pelos pobres (p. 77-79); Cap. 21: A rede (p. 89-91); Cap. 22: Conclusão, Maria, a Santa Mãe da Amazônia (p. 93-95).
} 
sem exclusões; diálogo com os povos e, especialmente os pobres e os culturalmente diferentes, com feridas provocadas pela colonização da qual, às vezes a Igreja foi cúmplice. Diálogo apoiado na abordagem cordial com outras culturas e que enfrenta resistência de interesses econômicos e de um paradigma tecnocrata contra a mudança e que querem se impor pela força.

$\mathrm{Na} 2^{\mathrm{a}}$ e $3^{\mathrm{a}}$ parte, articula-se a apresentação, desafios e propostas com as sugestões para enfrentá-los. Apresenta 18 desafios e, para enfrentá-los, 100 sugestões, algumas detalhadas em vários subitens. Na parte II - ECOLOGIA INTEGRAL: O CLAMOR DA TERRA E DOS POBRES trata da destruição extrativista, dos povos indígenas em isolamento voluntário, migração, urbanização, família e comunidade, corrupção, saúde integral, educação integral e conversão ecológica. Na parte III - IGREJA PROFÉTICA NA AMAZÔNIA - na questão da Igreja com rosto amazônico e missionário, enfrenta o desafio da interculturação e da interculturalidade, da liturgia inculturada na celebração da fé, da organização da comunidade, da evangelização nas cidades, do diálogo ecumênico e interreligioso, da missão dos meios de comunicação e, para finalizar, o papel profético da Igreja e a promoção humana integral.

Esta enumeração, que repete os títulos dos capítulos, não reproduz a riqueza do trabalho, mas mostra que ele fornece subsídios para a montagem de toda uma política, tanto em relação ao modelo socioeconômico, quanto para a atuação e transformação da Igreja. Pela sua amplitude não caberia analisá-la neste texto. Foi sobre ele que os grupos de trabalho se concentraram no sínodo. Em uma avaliação do evento sínodo, o mais importante é constatar o que do diagnóstico e das propostas fundamentadas, teológica e doutrinariamente 24 foi assumido na Exortação Apostólica em que o Papa incorpora a contribuição do sínodo no Magistério da Igreja.

24 SINODO DOS BISPOS. ASSEMBLEIA ESPECIAL PARA A REGIÃO AMAZÔNICA - Amazônia: novos caminhos para a Igreja e para uma Ecologia Integral. Documento Final, Vaticano, 26 de outubro de 2019, $26 \mathrm{p}$. Disponível em: Link. Acesso em: 29 jan. 2019, às 11:20. 


\section{Avaliando a cobertura}

\section{O condicionamento de notícias}

Ao passar da avaliação, baseada fundamentalmente em textos dos promotores do sínodo, para uma apoiada na análise da cobertura pela mídia, consideramos útil relembrar, sumariamente, os "critérios de noticiabilidade" utilizado pela mídia. Estes seriam o novo; o diferente do padrão, rotina, esperado; o inusitado, o polêmico ou que pode provocar polêmica. Estes critérios influem no agendamento (inclusão do assunto na pauta do veículo e da opinião pública) e no enquadramento (o modo como a notícia é construída a partir da visão e dos interesses dos veículos e das fontes).

Disso pode decorrer um deslocamento. De um lado, para avaliar uma política é importante conhecer o conteúdo dos documentos e pronunciamentos dos promotores. No caso do sínodo, por exemplo, o "Instrumentum Laboris". Com o passar do tempo, este projeto seria mais ou menos praticado pela organização, no caso, a Igreja Católica com suas dioceses ordens, clero e fiéis. Por outro lado, a percepção e repercussão, na política e na opinião pública, do acontecimento são definidos pela cobertura da mídia, que seleciona os fatos a partir dos seus interesses e critérios de noticiabilidade.

Traduzindo, podemos considerar como a mais importante contribuição do sínodo, a apresentação das crises socioambiental, a denúncia do modelo capitalista e as sugestões para efetivar uma igreja em saída. A cobertura da mídia pode utilizar outros critérios e produzir "acontecimentos" diferentes para os vários atores sociais.

Para a avaliação da cobertura utilizamos a mídia impressa: a Folha de São Paulo, o Jornal de maior circulação e matérias paradigmáticas das 4 revistas semanais. Todos divulgam suas notícias, também, através do site e redes sociais e, assim, ajudando a pautar outros veículos, minimizam a limitação da nossa análise. 
A expectativa da mídia

A Carta Capital que, antes da posse de Bolsonaro, apontara, em editorial, o Papa Francisco como seu futuro maior inimigo 25 , apresentou a convocação do sínodo já em fevereiro, logo após a reunião do Papa no Peru, com o enquadramento de oposição entre Igreja e governo. Capa, com foto do Papa Francisco em cartaz com grande legenda (comunista), em vermelho, e texto de apoio "O Papa Francisco convoca o sínodo sobre a Amazônia, em defesa dos seus povos e da preservação do Meio Ambiente. O governo Bolsonaro o enxerga como inimigo".

Editorial $^{26}$ ironizando a posição do Gal. Heleno, do Gabinete de Segurança Institucional, que acompanhava, com preocupação, a preparação do sínodo ${ }^{27}$. Ampla reportagem ${ }^{28}$ na qual lembra os ataques de Bolsonaro e bolsonaristas à CNBB, na campanha eleitoral, manifestações do Papa sobre a Amazônia, anteriores a Bolsonaro (2013, 2015 e 2017), critica o Gal. Heleno, apresenta falas de bispos brasileiros, relembra a repressão à Igreja e aos indígenas desde a Ditadura Militar, as ligações de Bolsonaro com religiosos conservadores, especialmente evangélicos, as reações conservadoras na Igreja Católica. Para o autor, o choque entre posições do governo e do Papa sobre a Amazônia era inevitável. A revista continuou cobrindo as ações da Igreja neste enquadramento durante o resto do ano. As matérias que selecionamos como emblemáticas da posição das demais revistas semanais ${ }^{29}$ sobre o sínodo aparecem às vésperas do sínodo quando, depois da polêmica em agosto, sobre as queimadas, a Amazônia era tema inescapável.

ISTO É publicou uma curta matéria informativa ${ }^{30}$. Informa que o sínodo começaria no dia 7, com o lema "Amazônia, novos caminhos para a Igreja e para uma ecologia integral. Informa que o Sínodo seria uma "assembleia de religiosos" para debater temas específicos; manteria o espírito de colegialidade; fora instituído pelo Papa Paulo VI em 15/09/1965, é

25 O maior inimigo. Papa e Governo Bolsonaro, há de ser o Papa Francisco. Carta Capital, São Paulo, 03 dez. 2018. Cartacapital.com.br, acesso em 30 jan. 2020.

${ }^{26}$ Carta Mino. A nova face do Kremlin. Carta Capital, 1042, São Paulo: Confiança, 20 fev. 2019, p. 12.

${ }^{27}$ A divulgação pelo Jornal Estado de São Paulo, no dia 10 fev. 2019, de que agentes da ABIN - Agência Brasileira de Investigações acompanhava a preparação do sínodo provocou grande reação no mundo político.

${ }^{28}$ BARROCAL, André Farda. VS Batina. Carta Capital, 1042, São Paulo: Confiança, p. 16-22.

${ }_{29}$ Análise de toda a cobertura é trabalho a ser feito, mas quer ultrapassa as dimensões desse artigo. As matérias selecionadas nos parecem representativas.

${ }^{30}$ Saiba mais sobre o Sínodo da Amazônia, Isto É, São Paulo, o6 out. 2019. Disponível em: Link. Acesso em: 21 abr. 2020. 
convocado pelo Papa que designa seus membros e produz documento com recomendações. O Papa Francisco convocou 4 sínodos nos 6 anos do pontificado -2 sobre família e um sobre jovens. O da Amazônia reuniu cerca de 250 pessoas, 113 padres sinodais. Segundo dados do Vaticano, participariam 28 Cardeais, 29 arcebispos, 62 bispos, 7 bispos auxiliares, 27 vigários apostólicos, 10 bispos prelados e 21 membros não bispos. Também participaram 12 convidados especiais e 25 especialistas. Cerca de 35 mulheres - religiosas em maioria - assistiriam mas não poderiam votar. Na Revista, a parte política fica com o cardeal brasileiro Cláudio Hummes que disse que o sínodo era importante, devido à grave e urgente crise socioambiental, prevista pela Encíclica "Laudato Si". Entre os problemas apontados estariam o aquecimento global, o efeito estufa, a crise ecológica, com consequências da degradação, polvição e devastação da Amazônia, a crescente pobreza e miséria que afeta grande parte dos indígenas dessa região, as populações ribeirinhas, os pequenos agricultores e os que vivem nas periferias das cidades amazônicas.

A ÉPOCA, revista do grupo "O Globo", na capa, colocou uma batina branca sobre o fundo verde da floresta, com a legenda "O jogo de forças entre o Papa Francisco e Bolsonaro pode marcar a assembleia que começa neste domingo, mas o encontro terá implicações que irão muito além". Editorial, "fé cega, faca amolada"31. Nele confronta a convocação do sínodo com declarações de Bolsonaro no mesmo mês (outubro de 2017), no Círio de Nazaré, em Belém, prevendo, no seu governo, o fim do politicamente correto e a mudança na política mineral, relembra suspeitas sobre o sínodo e monitoramento da ABIN. Assim, "o embate entre o progressismo de Francisco e o reacionarismo de Bolsonaro é real", mas, acrescenta, "há muito mais coisas envolvendo a Igreja e a floresta do que supõe o Bolsonarismo". Cita Jonh Allen Jr., autor vaticanista e autor da matéria de capa da Revista que afirma a importância do sínodo para o mundo e que coloca que o foco da disputa não seria entre o Presidente do Brasil e o Papa, mas no coração da Igreja - com os conservadores na questão ambiental e na ordenação dos homens casados. Mas, conclui a ÉPOCA, a atenção mundial estará focada no Vaticano, durante quase todo o mês de outubro "e é isto que assusta o governo".

${ }^{31}$ ÉPOCA, 1109, Rio de Janeiro: Globo, 04 out. 2019 - Link Acesso em: 14 abr. 2020, às 15h40. 
A VEJA, de posição historicamente liberal, contra os progressistas da Igreja Católica, às vésperas do sínodo, faz uma grande reportagem sobre a indicação do Cacique Raoni para o Prêmio Nobel da Paz, como expressão da oposição ambientalista a Bolsonaro ${ }^{32}$. Sob o título da matéria, a frase: "agressões de Jair Bolsonaro ao Cacique deram impulsos à campanha do líder indígena para receber a distinção, inédita no Brasil". As agressões ocorreram, inclusive, em fala de Bolsonaro na Assembleia Geral da ONU (24/09/2019) e estimularam uma campanha iniciada em maio. A matéria contém boa reconstituição da vida e posições de Raoni. Quanto ao que poderia remeter ao Sínodo, apenas uma das fotos mostra Raoni abraçando o Papa Francisco ("preocupações com o meio ambiente") e, no fim, denúncia do CIMI de que, em 2019, até setembro haviam aumentado as invasões de terras indígenas.

\section{O desenrolar do Sínodo}

Avaliando a cobertura do que aconteceu durante o Sínodo, cabem duas observações preliminares. A primeira, que reuniões de comissões de trabalho, debatendo textos, geralmente não são espaços mais propícios, a identificação de fatos que preencham os "critérios de noticiabilidade" da mídia. Outra é que, durante o sínodo, o foco em evento da Igreja Católica foi desviado, na imprensa brasileira e, mais ainda, na baiana, pela cerimônia de canonização de 5 Santos33, um dos quais Irmã Dulce. A sua canonização, no dia 13 de outubro de 2019, em Roma, atraiu a atenção da população e mídia brasileira, e a grande missa em Salvador, no Estádio da Fonte Nova, no dia 20 mesmo mês, foi a grande pauta de toda a mídia baiana ${ }^{34}$.

$3^{2}$ GHIROTTO, Eduardo; ZYLBERKAN, Mariana. A campanha que pretende fazer de Raoni o primeiro Prêmio Nobel Brasileiro, Veja, 2655, São Paulo, Abril, 04 out. 2019. Acesso em 14 abr. 2020, às 10 h3.

33 John Henry Newman (1801-1880) Cardeal fundador do Oratório de São Felipe Nery, Inglês; Giuseppina Vannini, Madre Josefina, italiana (1851-1914) fundadora dos Filhos de São Camilo, Mariam Tereza Chirame Mankipiyan (1875-1926) indiana, fundadora da Congregação das irmãs da Sagrada Família e Margherita Bays (1815-1879) suiça, leiga da Ordem Terceira de São Francisco de Assis. Irmã Dulce (1914-1992), como se vê é a única nascida no século XX. Dentre os outros, o cardeal Newman, inglês, anglicano, convertido e potente pensador, tinha nome bastante conhecido na Europa. Representando a Rainha Elizabeth II, o príncipe Charles compareceu a cerimônia.

34 Por exemplo, a Missa de Canonização, em Roma, foi transmitida na íntegra pela Rede Bahia. Na Bahia, a TV Bahia transmitiu a íntegra da $1^{a}$ Missa no Brasil. 
Exemplo maior, na imprensa nacional, do deslocamento do foco, para nós, foi dado pela "Veja". Matéria de capa, "Multiplicação de santos", com retrato de Irmã Dulce e subtítulo "com número recorde de canonizações", inclusive da freira baiana Irmã Dulce, a "Igreja Católica tenta recuperar o rebanho perdido". Dentro, editorial e ampla matéria sobre Irmã Dulce, com o mesmo enquadramento. Na matéria, foto do Papa e frase sobre o Sínodo, ambas apontando para "atalho para atrair mais gente"35.

A celebração de Irmã Dulce foi, praticamente, uma unanimidade nacional ${ }^{36}$, mas, para mostrar que a estranheza entre o governo Bolsonaro e o Vaticano continuava, a imprensa assinalou que ele não fora à cerimônia e enviara o vice Presidente, o Gen. Mourão. Foi levantado que isso ocorreu a pedido de sua esposa evangélica, mas podemos aventar que as divergências com o Papa Francisco tenham influído. Para nós, brasileiros, que reconstituímos a história do sínodo, uma singularidade. A convocação do sínodo desviou o foco da canonização de 30 santos brasileiros e a canonização de Irmã Dulce desviou, temporariamente, o foco dos trabalhos do sínodo37.

À medida que os trabalhos do Sínodo se aproximavam do fim, identificamos textos sobre o mesmo. Uma série de matérias publicadas, na Folha de São Paulo, é um bom exemplo de aplicação dos critérios de noticiabilidade. Passemos a elas.

\section{Possibilidade de criação de um novo pecado - o ecológico $3^{8}$}

Tema teria aparecido no $2^{\circ}$ dia (o8 de outubro) e as discussões sobre a conversão ecológica que já eram defendidas na "Laudato SI", o Instrumento de Trabalho denunciou as estruturas de pecado na região. Ao final, o importante seria uma reflexão sobre o conceito e não uma relação de pecado.

35 Carta ao leitor. Sinais que vem de Roma, Veja, 2656, São Paulo: Ed. Abril, 16 out. 2019, p. 12. LOPES, Adriana. Menos fiéis, mais santos, Veja, 2656, São Paulo: Ed. Abril, 16 out. 2019, p. 70-75.

${ }^{36}$ Apresentada como a primeira santa nascida no Brasil, contemporânea ou conhecida pela maioria dos brasileiros, irmã Dulce (hoje Santa Dulce dos Pobres) já era reconhecida como santa pelos pobres a quem assistia, pelos ricos e poderosos a quem pedia recursos e por setores médios que acompanhavam (as vezes com contribuições) o trabalho da OSID - Obras Sociais Irmã Dulce.

37 No caso, cabe lembrar o obvio. O martírio dos 30 ocorrera há 374 anos e era desconhecido pela maioria dos brasileiros, Irmã Dulce foi canonizada 27 anos após a morte e era conhecida pessoalmente e por filmes e fotos, por milhões de brasileiros.

$3^{8}$ OLIVEIRA, Michele. Assembleia de Bispos da Amazônia discute criação de pecado ecológico. Folha de São Paulo, São Paulo, 20 out. 2019, p. A18. O super lead da matéria era menos ambicioso - mais preciso, "Debate no Vaticano resultou em documento a ser votado com indicações para os católicos". 


\section{Missionários abandonaram conversão religiosa com os indígenas 39}

Não se trata exatamente de abandono do trabalho de evangelizações e conversão, conforme o próprio texto mostra, mas de uma forma diferente da dominante até o século XX. Na matéria, D. Roque Paloschi, arcebispo de Porto Velho e Presidente do CIMI Conselho Indígena Missionário, informa que o CIMI contava com 171 missionários, divididos em 11 Regionais e que, na delegação que enviara ao sínodo havia índios e missionários leigos. O CIMI dá apoio sem pressão para a conversão ao catolicismo. Não seria evangelização explícita, mas implícita, mostrando, diz leigo, que, os cristãos são bons, que Deus é bom e valorizando sua cultura. O arcebispo disse "a evangelização não é entregar um pacote pronto, mas traçar caminhos com a população" [...], "não pode negar sua tradição, seus costumes, sua história. Do contrário, evangelização se torna colonização.

A matéria é gancho para rebater ataques conservadores às mudanças na liturgia e à possibilidade de padre casados e maior participação das mulheres. A página é completada com matéria mostrando a reação conservadora, e da Ditadura Militar, contra a atuação da Igreja e da luta dos índios pelos seus direitos, a qual inclui a proibição, pela FUNAI, da participação de cacique brasileiro na Conferência de Puebla $4^{40}$.

\section{Mulheres reivindicando espaço ${ }^{41}$.}

A matéria começa com o inusitado. A fala de Anitalia Pijachi Kuyuedo, 40' indígena, líder dos Okaira - Muina Murui, da fronteira da Colômbia com Tabatinga (AM), cuja foto com o Vaticano ao fundo, ilustra a matéria. "Qual o medo que vocês têm das mulheres? Vou dizer algo a cada um dos homens sentados: se vocês podem ver a luz do dia, o seu rosto raspou a vagina de uma mulher. E se não fizeram isso, deixaram uma marca impagável no ventre de uma mulher. E mesmo assim, os amamos. Não se esqueçam de onde vieram [...] $\mathrm{E}$

39 LOPES, Reinaldo. Missionários abandonam conversão religiosa ao se aproximar dos indígenas. Folha de São Paulo, São Paulo,21 out. 2019, p. A15. O super lead anunciava: Vaticano amplia foco e debate temas polêmicos para igreja em encontro com bispos da Amazônia.

40 SPERB, Paula. Há 40 anos a ditadura proibiu líder de encontrar Papa no México. Folha de São Paulo, São Paulo, 21 out. 2019, p. A14.

${ }^{41}$ MISSIONAVE, Fabiano. Mulheres celebram espaço, mas querem mais. Folha de São Paulo, São Paulo, 26 out. 2019, p. A14. 
nos deem o lugar que merecemos". Recebeu calorosos aplausos e um bispo assinalou que fora a primeira mulher, indígena, que, neste cenário, em milhares de anos, pronunciou a palavra vagina. Pijachi, auditora no sínodo, estava indignada com as falas inicias dos bispos contra a criação de um ministério oficial para as mulheres. A matéria anuncia, ainda, que participantes ouvidas pela FOLHA avaliaram que o sínodo avançara ao ampliar a voz feminina, ressalvando que o direito a voto continua reservado aos padres sinodais. Cita nominalmente duas brasileiras, a irmã Roseli Bertoldo, auditora, e a socióloga Márcia Maria de Oliveira, da Universidade Federal de Roraima, que fora a mulher entre os 5 especialistas que elaboraram o documento preparatório do sínodo e era umas das 5 peritas (de 25) que o acompanhavam.

\section{As polêmicas e o balanço}

No dia 27, quando se encerrava, e no dia 28, matérias avaliam o sínodo e apresentam suas conclusões.

Na FSP, no dia 27, grande matéria avalia politicamente o sínodo na perspectiva da polêmica entre a esquerda católica latino americana, adepta da Teologia da Libertação (TL) e os conservadores ${ }^{42}$. O uso do anel de Tucum por muitos participantes, a convergência entre as propostas para aumentar a presença da lgreja nas regiões distantes e as CEBs Comunidades Eclesiais de Base, o reforço que é a orientação de inter-culturalidade na relação com os povos indígenas da linha do CIMI, seriam exemplos da força dos adeptos da $\mathrm{TL}$, para a qual a Amazônia teria permanecido como reduto, enquanto perdera espaço no Sul e Sudeste. Acresce que a proposta de ecologia integral, da Encíclica "Laudato SI", já estava presente nos trabalhos de Leonardo Boff quando este fora expoente da TL e no presente.

Por outro lado, os conservadores questionavam sobre a aproximação com as esquerdas e o comunismo, a ordenação de homens casados, o diaconato das mulheres, o uso de imagens religiosas indígenas e elementos de sua cultura. No dia 25/10, em entrevista coletiva, a jornalista Diane Montagna, do "Life Site", perguntou ao bispo de Marajó,

\footnotetext{
$4^{2}$ MAISONNAVE, Fabiano. Sínodo da Amazônia reenergiza teorias da Teoria da Libertação, Folha de São Paulo, São Paulo, 27/10/2019, p. A18.
} 
Evaristo Splenger sobre seu suposto encontro com deputados brasileiros, socialistas e comunistas e afirmou que "Jesus Cristo estabelecera que o sacerdócio fora reservado aos homens". O bispo negou o suposto encontro e lembrou que Bento XVI alterara a lei canônica abrindo espaço para o diaconato das mulheres. A matéria fala de que imagens indígenas foram "vandalizadas". Matéria de A Tarde, esclarece mais - na fala de encerramento, o papa Pediu desculpas pelo roubo de imagens 43 indígenas de madeira, que estavam em igreja próxima do Vaticano.

A FSP completa o balanço, no dia 27 e $28^{44}$, mostrando o fortalecimento, ainda que cauteloso, da linguagem da esquerda.

O fortalecimento da Teologia da Libertação se comprovaria pela composição do Conselho pós sínodo, encarregado de monitorar a implantação das decisões que, "após aprovação pelos padres sinodais, dependerão da sanção final do sumo pontífice". Na verdade, as conclusões do sínodo vão subsidiar o Papa para elaborar o documento Exortação Apostólica.

Foram eleitos 13 conselheiros e o Papa nomeou mais 3. Dos 4 brasileiros, 2 o autor identifica como identificados com a TL - o bispo emérito do Xingu, D. Erwin Kratler e o presidente do CIMI e bispo de Porto Velho, D. Roque Paloschi. Os outros 2 são o Cardeal Cláudio Hummes, relator geral do sínodo, (grifo nosso) e o bispo de Belém. Anunciou que, no dia 28, o seguinte ao encerramento, seria aberta, no Museu do Vaticano, a exposição. "Mater Amazônia", que inclui o espaço para homenagear lideranças assassinadas na região como Dorothy Stang.

No dia 28, a cobertura do encerramento, com a fala do Papa na Missa de Encerramento, informações sobre as propostas do documento final e avaliações sobre o futuro da Igreja. Do encerramento somos informados ${ }^{45}$ que, no sábado (26), fora divulgado o documento de 33 páginas. As recomendações atingiam:

${ }^{43}$ Papa anuncia criação de órgão para Amazônia no Vaticano, A Tarde, 27 out. 2019, p. B5.

44 LOPES, Reinaldo José. Sínodo da Amazônia se esforça em não avançar sinal vermelho. Folha de São Paulo, São Paulo, 28 out. 2019, p. A15.

45 MAISONNAVE, Fabiano. Saque desfigura o rosto da Amazônia, diz Papa. Folha de São Paulo, São Paulo, 28 out. 2019, p. A 15. 
a) O modelo econômico - aliança da igreja com os povos amazônicos para denunciar o "modelo econômico de desenvolvimento predatório e ecocida" e os projetos que afetam o meio ambiente;

b) Ordenação de padres casados, para compensar falta de padres na Amazônia;

c) Criação de pecado ecológico - atos e hábitos de polvição e destruição da harmonia do ambiente;

d) Igreja intercultural, com respeito a história cultural, estilo de bem viver;

e) Mulheres - ampliar espaço de presença, mas deixando a questão do diaconato para aprofundamento;

f) A criação de um observatório pastoral sócio ambiental

Na missa, que encerrou o evento, a indígena brasileira Marcivana Sateré, do povo Sateré - Mawé subiu ao altar para entregar um vaso ao Papa Francisco com milho e feijão plantados no início do Sínodo. O jornalista se refere, evidentemente ao rito do "ofertório". O Papa, na hora da "homilia", fez veemente denúncia e apelo: "os erros do passado não foram suficientes para deixarmos de saquear os outros e causar ferimentos aos nossos irmãos e à nossa irmã terra. Vimos isto no rosto desfigurado da Amazônia". É a matéria com que a FSP encerra a cobertura local do sínodo $4^{4}$.

Lopes tenta uma avaliação global, comparando o Sínodo como os anteriores. Diferente dos predecessores (Bento XVI e João Paulo II), os sínodos convocados pelo Papa Francisco não serviam mais para referendar agenda pré-estabelecida, mas são abertos à discussão e à diversidade na Igreja. Os sínodos procurariam combinar linguagem cautelosa e esforço para não avançar o sinal vermelho doutrinário com a deflagração de processos transformadores: inovações propostas como a ordenação de padres casados e a liturgia amazônica têm similares nas tradições e ritos orientais da própria Igreja Católica. E no tema, adiado, das diaconisas se buscava apoio na participação das mulheres no cristianismo primitivo; o sínodo, além de preocupação com o ambiente e justiça social, revelaria a visão de que, nas periferias globais, estaria o futuro do catolicismo.

\footnotetext{
$4^{6}$ Comprovando este fato, no fim da matéria, informa "o repórter Fabiano Maisonnave viajou a Roma, a convite da Burness Communications.
} 
Finalizando a cobertura "in loco", no dia 1 de novembro, nota informa sobre extensa entrevista de Dom Cláudio Hummes, ao jornal italiano "La Stampa", onde ele avalia que o sínodo foi além da expectativa, abriu a porta para novo momento na região e rebate duramente as críticas conservadoras à suposta "idolatria indígena"; dizendo que "quem os fez sabe mentir"47.

Encerrando o Sínodo, passa-se à etapa da implantação das suas sugestões.

\section{Papa: estímulo a partir do Sínodo}

A posição do Papa sobre o sínodo da Amazônia foi divulgada, no dia 02 de fevereiro, com a publicação da "Exortação Apostólica" 48 ao povo de Deus e todos os homens de boa vontade 49 .

A repercussão na mídia comercial foi pequena e se concentrou na não aceitação da ordenação de homens casados para a Amazônia ${ }^{50}$. Ocorreu um conflito entre dois critérios: o da noticiabilidade da imprensa e o da importância do que, assumido pelo Papa, se incorpora ao Magistério da Igreja.

Não poderíamos concluir este artigo sem apresentar, ainda que sumariamente, 0 conteúdo da Exortação. O resumo se permite, para as Ciências Sociais, visualizar a posição da Igreja Católica, é incapaz de repassar a riqueza doutrinal e poética (a Exortação inclui várias poesias) do texto, que deve ser lido integralmente.

Da introdução do texto destacamos: a apresentação oficial das conclusões do sínodo; "Amazônia: novos caminhos para a Igreja e para uma Ecologia Integral" feito, segundo o Papa, por pessoas que conhecem a realidade mais do que ele e a Cúria Romana e que sugere a leitura. Oferece um quadro de reflexão que encarna na realidade amazônica, uma síntese que ajuda na orientação para uma "recepção harmoniosa, criativa e frutuosa do caminho do sínodo" (A chave é a palavra recepção do que o Papa incorpora ao Magistério da Igreja); defende que a problemática da Amazônia interessa a todo o mundo e não,

\footnotetext{
47 SÁ, Nelson de. Toda mídia, Folha de São Paulo, São Paulo,1º nov. 2019, p. A24.

$4^{8}$ O VATICANO. Querida Amazônia. Exortação Apostólica Pós-Sinodal, Roma o2 de fevereiro, 2020. Disponível em: Link Acesso em: 03 abr. 2020, as 15h35.

49 Ao referir-se à Igreja como "Povo de Deus" o Papa mostra sua filiação a concepção do Concílio Vaticano.

$5^{\circ}$ Este também foi manchete da Folha de São Paulo que cobrira mais o sínodo, ainda que no texto da matéria tenha apresentado um resumo de outras conclusões.
} 
apenas, aos 9 países da região e a necessidade da proposta de Encarnação da Igreja de modo original na Amazônia.

A partir daí, detalha o seu projeto na forma de 4 sonhos.

O sonho social (\$8-27)

O sonho social é a integração e promoção de todos os habitantes para o "bem viver", para o que propõe um gesto profético, o empenho pelos mais pobres, ouvir o clamor da terra e negar o conservadorismo que se preocupa com o bioma e ignora o povo amazônico. A denúncia da ação, legal ou ilegal, antiga ou atual, da colonização é contundente. Ação de madeireiros, pecuaristas, construtores; privatização da água potável, penalização dos protestos, assassinatos, provocação de incêndios florestais, suborno de políticos e dos próprios índios. Esta ação estimulou as migrações para a periferia das cidades onde encontram novas formas de escravidão ${ }^{11}$. O Papa dá exemplos de violência no passado que chegaram ao "sadismo mais absurdo" e alerta que esta colonização continua. Autoridades tornam-se instrumentos da morte e a corrupção degrada as instituições, podendo atingir setores da Igreja. Nela, o Papa elogia os que foram fiéis ao Evangelho e pede perdão pelos erros na colonização.

O Papa denuncia "falsa mística", defendida nos últimos decênios do século XX, que apresentaria a Amazônia como enorme vazio a preencher, riqueza em estado bruto, vastidão selvagem a ser domada, desconhecendo ou ignorando os direitos dos povos nativos.

A condenação é dura. "Operações econômicas nacionais ou internacionais que danificam Amazônia e não respeitam os direitos dos povos nativos ao território e sua demarcação, a autodeterminação e consentimento prévio, há que rotulá-las com o nome devido: "injustiça e crime" ( $(14)$.

O Papa apresenta fundamentação no Evangelho para a indignação, mas afirma que é possível superar a mentalidade de colonização, construindo redes de solidariedade e de desenvolvimento, uma globalização na solidariedade com alternativas sustentáveis na

\footnotetext{
${ }^{51} \mathrm{Na}$ época da Ditadura Militar a colonização era promovida também com o slogan "Gente sem terra para terra sem gente". Na prática, as maiores beneficiadas foram as empresas.
} 
agricultura e pecuária, energia não polvente, trabalho construtivo e educação que empodere pobres e indígenas.

A saída proposta é a Amazônia como espaço de diálogo social, especialmente entre os povos nativos e no qual os pobres, marginalizados e excluídos devem ser protagonistas.

O sonho cultural $(\$ 28-40)$

O sonho cultural é o de "renovar a Amazônia e ela própria tirar o melhor de si mesma a partir de uma educação para cultivar sem desenraizar, fazer crescer sem enfraquecer a identidade, promover sem invadir" (\$28).

Os vários povos amazônicos criaram culturas diferentes que foram ameaçadas pelas migrações das margens para o interior da floresta e, hoje, para a periferia das cidades, onde perdem referências, raízes culturais, interrompem a transmissão cultural e se tornam descartáveis. Assim, é necessário enfrentar a visão homogeneizadora e consumista imposta pela globalização e assumir as raízes (que, para os batizados, inclui a história da Igreja), valorizando os saberes tradicionais, apoiando-se no sentido comunitário das etnias, que desenvolveram culturas em conexão com a natureza.

A partir das raízes, identidades e visões promover o encontro intercultural, enfrentar os danos da economia globalizada, a colonização promovida pelos meios de comunicação, através de redes de comunicação alternativas e de protagonismo dos atores sociais locais.

O sonho ecológico $(\$ 41-60)$

O sonho ecológico parte da consciência de que tudo está interligado, da relação entre ecologia natural (respeito pela natureza) e ecologia humana; da inseparabilidade dos cuidados com pessoas e ecossistemas, da necessidade de defender a Mãe Terra dos maus tratos, inclusive das multinacionais.

Em relação à Amazônia, realça a importância da água e do Rio Amazonas, hoje ameaçados, no eixo das muitas "amazônias"; a dependência que o equilíbrio da terra, do clima, da biodiversidade tem da saúde da Amazônia e das florestas tropicais, que evitam o aquecimento da terra e, se destruídas, deixam o solo pobre. 
Os interesses das empresas não podem ser colocados acima do bem da Amazônia e da humanidade inteira. O Grito da Amazônia (pobres e terra) é similar ao do Povo de Deus no Egito. A partir daí apresenta as soluções para a Amazônia ${ }^{52}$.

a) A solução não está na internacionalização até pela presença de interesses externos internacionais, mas na responsabilidade dos governos nacionais e na pressão sobre eles das organizações internacionais e da sociedade civil;

b) A intervenção no território deve ser feita de forma sustentável e com informações submetidas aos povos nativos;

c) Criar sistema normativo (leis) com limites invioláveis (pela ganância) e que proteja os ecossistemas;

d) Educação que desenvolva novos hábitos, estilos de vida contra o consumismo e cultura do descarte;

e) Contemplar, sentir-se unido à Amazônia, que é um lugar teológico onde o próprio Deus se manifesta.

Após apresentar os 3 sonhos, o Papa afirma que "a Igreja com sua longa experiência espiritual, a sua consciência renovada sobre o valor da criação, a sua preocupação com a justiça, a sua opção pelos últimos, a sua tradição educativa e a sua história de encarnação em culturas tão diferentes [...] deseja prestar a sua contribuição para o cuidado e o crescimento da Amazônia".

Neste momento, há uma mudança na Exortação, um sonho a ser partilhado "mais diretamente com os pastores e os fiéis católicos".

O sonho eclesial ( $(61-110)$

Na perspectiva de posicionamentos de consequências políticas imediatas, é a parte mais difícil de resumir. Não apenas pela dimensão do texto e da fundamentação53, mas porque o conteúdo teológico e doutrinal, mais que justificativa, é parte essencial do posicionamento.

\footnotetext{
${ }^{2}$ Respeitando e resumindo o texto, a itemização é de nossa responsabilidade.

53 Os 50 parágrafos correspondem a $45 \%$ do texto e as 70 notas a $48 \%$ das mesmas.
} 
Assim, decidimos não tentar resumir. Mas, agrupar a fala do Papa54 em 4 blocos:

a) A afirmação da especificidade - o necessário anúncio do Evangelho;

b) A necessidade de encontrar e promover uma ampla inculturação;

c) A necessidade de, para a inculturação, rever o papel dos padres, leigos e mulheres;

d) A superação de conflitos e a convivência ecumênica e inter-religiosa.

\section{O necessário anúncio}

Sua caminhada com os povos da Amazônia é antiga e a opção pelos pobres impele a Igreja, ao mesmo tempo, para lutar para libertá-los da miséria e propor-lhe o Evangelho. Têm direito ao anúncio cujo conteúdo principal é o Querigma (Deus que ama infinitamente cada ser humano, que manifestou plenamente este amor em Cristo crucificado por nós, ressuscitado na nossa vida) e à caridade fraterna que resulta do seu aprofundamento.

Contentar-se com o anúncio social seria não atender a Jesus "ide pelo mundo inteiro, proclamai o Evangelho a toda a criatura" (MC, 16, 15). E a Igreja se transformaria em uma ONG. Com esta posição o Papa responde, simultaneamente, a fala dos conservadores de que, na ação social, a Igreja estaria atuando como partido ou ONG e a daqueles, "progressistas", que aceitam que ela ajude, mas propõem que não interfira na cultura.

\section{A necessária inculturação}

Para crescer na Amazônia, a Igreja deve respeitar e dialogar com as culturas, recebendo e plenificando o que de bom lá exista. É uma relação de mão dupla - a mensagem do Evangelho tem força transformadora e a Igreja se enriquece com o que o Espírito Santo já semeara na cultura. Daí surge uma nova síntese. O cristianismo não dispõe de um único modelo cultural. Um cristianismo monocultural e monocórdico seria um risco a evitar, pois contra a lógica da encarnação55.

54 O que aumenta, para os católicos, a quem o texto se destina, a importância da leitura e meditação do texto.

55 O Papa [...] reconheceu o risco dos evangelizadores que "chegam a um lugar e julgam que devem comunicar [...] também a cultura em que nasceram". Mais do que risco, acrescentamos uma tendência, dificilmente 
A Igreja, na Amazônia, precisa de uma inculturação social, espiritual e na liturgia. Para isto, receber e valorizar sabedoria, estilos de vida, concepção do "bem viver" dos indígenas, inclusive para enfrentar o consumismo e o individualismo; reconhecer a conexão entre defesa de direitos e atendimento dos anseios pelo transcendente; articular a visão dos indígenas de Deus presente no Cosmo com o encontro com um Deus pessoal; respeitar traços do catolicismo popular (símbolos, mitos, festas) e levar à união com Deus ligado ao cotidiano, à vida e à alegria. Nos sacramentos, a natureza é assumida por Deus e transformada em mediação. Assim, na liturgia se pode receber cantos, danças, ritos, gestos e símbolos. Propostas, aliás, do Concílio Vaticano II, que avançam devagar.

\section{Padres, comunidades, mulheres}

Depois de avançar no caminho, o Papa pergunta "se se incultura a espiritualidade, [...] a santidade [...], o próprio Evangelho será possível evitar de pensar numa inculturação do modo como se estruturam e vivem os ministérios eclesiais?" (parágrafo 89). A partir daí, enfrenta problemas sensíveis - o primeiro a escassez e o papel dos padres.

É necessária a celebração da Eucaristia nos lugares mais distantes da Amazônia. Os leigos podem anunciar a palavra, ensinar, organizar suas comunidades, celebrar alguns sacramentos, buscar expressões da fé, desenvolver seus dons. Mas precisam da celebração da Eucaristia. Aqui, caberia a ordenação de homens casados. O Papa escolheu uma estratégia diferente:

a) Definir o específico e indelegável do sacerdote - não é o poder na comunidade mas celebrar a Eucaristia e perdoar os pecados;

b) Exortar os bispos para orarem por vocações e encaminharem missionários;

c) Mais espaço e poder para diáconos, religiosos e leigos, para desenvolver cultura eclesial marcadamente laical;

d) Valorizar as Comunidades de Base, o serviço da REPAM e os grupos missionários itinerantes. 
Quanto às mulheres, o sínodo já não havia incluído a proposta de ordenação. O Papa, sensibilizado pelo testemunho no sínodo56, afirma que a ordenação seria um reducionismo, que as clericalizaria, que elas devem contribuir do modo que lhes é próprio, que, sem as mulheres sustentando e cuidando, a Igreja desmoronaria, que elas devem participar da organização e das decisões, que se deve estimular o aparecimento de serviços e carismas femininos e que as que têm papel central nas comunidades devem ter acesso às funções e serviços ${ }^{57}$ estáveis, com reconhecimento público e envio pelo bispo ${ }^{58}$.

Em síntese, sem ordenação de homens casados ou mulheres, mas pressão para envio de mais padres e, especialmente, mais participação e poder para leigos e mulheres.

\section{A superação dos conflitos}

A Igreja deve ampliar os horizontes com propostas que integrem e superem os conflitos; inspirando-se no início do cristianismo, buscar caminhos ousados de encarnação na Amazônia; dialogar, valorizando o que nos une para trabalhar pelo bem da Amazônia e afirmar a identidade, que inclui a profunda devoção à Maria.

Por isso, após partilhar sonhos e indicar caminhos para transformar a realidade, o Papa achou melhor concluir com "A MÃE DA AMAZÔNIA", poema dirigido à Maria.

\section{Breve conclusão: o significado do Sínodo}

A promoção do Sínodo da Amazônia é parte de uma política do Papa Francisco que, a nosso ver, apresenta dois desafios à Igreja:

a) Assumir a defesa da natureza na perspectiva já explicitada na "Laudato si", de que tudo está interligado e que se deve enfrentar a cultura do descarte com um novo modelo civilizatório;

b) Prosseguir o Concílio Vaticano II, transformando-se em meio mais adequado de testemunhar a fé.

\footnotetext{
${ }^{56}$ É uma das poucas referências específicas ao sínodo no texto.

57 Ressalva os que não requerem ordenação.

${ }^{8}$ Por envio pelo bispo, entendemos mandato. Função estável, pública e representando o bispo é posição reconhecida de poder.
} 
Ao programar o Sínodo, a Igreja Católica decidiu enfrentar estes desafios, exatamente, em uma região de fronteira, chave para a expansão do modelo capitalista predador, a partir da qual se poderá construir resistências e alternativas. A construção de novo modelo civilizatório exige conversões, inclusive, na própria Igreja.

\section{Referências}

ALTERMEYER JR., Fernando. Os muitos partos do bispo de Roma. In. PASSOS, João Décio; SOARES, Afonso M. L. (Org.). Francisco: renasce a esperança. São Paulo: Paulinas, 2013.

ASSEMBLEIA ESPECIAL DOS BISPOS. Amazônia, novos caminhos para a Igreja e uma ecologia integral Instrumentum Laboris. Para a Assembleia Especial do Sínodos dos Bispos para a região Pan-Amazônica. Brasília: edições CNBB, 2019.

BARROCAL, André. Farda vs Batina. Carta Capital, n. 1042, São Paulo: Confiança, 2019, p.16-22.

CARTA AO LEITOR. Sinais que vem de Roma. Veja, n. 2656, São Paulo: Abril, 2019, p. 12.

CARTA, Mino. A nova face do Kremlin. Carta Capital, n. 1042, São Paulo: Confiança, 2019, p. 12.

CARVALHO NETO, Joviniano Soares de. Igrejas e Ditadura Militar na Bahia. Salvador: SAGGA, 2018.

CASALDALIGA, Pedro. Creio na justiça e na liberdade. Rio de Janeiro: Civilização Brasileira, 1976.

COMISSÃO MUNDIAL SOBRE O MEIO AMBIENTE E DESENVOLVIMENTO. Nosso Futuro Comum. Rio de Janeiro: Fundação Getúlio Vargas, 1988.

EDITORIAL. O maior inimigo. Papa e Governo Bolsonaro, há de ser o Papa Francisco. Carta Capital de 03.12.2018. Acesso em 30.01.2020.

EDITORIAL. Fé cega faca amolada. Época, 04.10.2019. Disponível em

https://epoca.globo.com/sociedade/fe-cega-faca-amolada-23995178. Acesso em 14 abr. 2020.

GHIROTTO, Eduardo, ZYLBERKAN. A campanha que pretende fazer de Raoni o primeiro Prêmio Nobel Brasileiro. Veja, n. 2655, São Paulo: Abril, 2019.

SAIBA mais sobre o Sínodo da Amazônia. Isto é,São Paulo, 06 out. 2019. Disponível em https://istoe.com.br/saiba-mais-sobre-o-sinodo-da-amazonial. Acesso em 21 abr. 2020.

HUMMES, Claudio. O Sínodo para a Amazônia. Cardeal D. Claudio Hummes. São Paulo: Paulus, 2019.

LOPES, Adriana. Menos fiéis, mais santos. Veja, n. 2656, São Paulo: Abril, 2019, p. 70-75.

LOPES, Reinaldo José. Sínodo da Amazônia se esforça em não avançar sinal vermelho. Folha de São Paulo, 28 out. 2019, p. A15. 
LOPES, Reinaldo José. Missionários abandonam conversão religiosa ao se aproximar dos indígenas. Folha de São Paulo, São Paulo, 21 out. 2019, p. A 15.

MAISONNAVE, Fabiano. Saque desfigura o rosto da Amazônia, diz Papa. Folha de São Paulo, São Paulo, 28 out. 2019, p. A 15.

MAISONNAVE, Fabiano. Sínodo da Amazônia reenergiza teorias da Teoria da Libertação, Folha de São Paulo, São Paulo, 27 out. 2019, p. A18.

MAISSIONAVE, Fabiano. Mulheres celebram espaço, mas querem mais. Folha de São Paulo, São Paulo, 26 out. 2019, p. A 14 .

MEADOWS, D. L. et. al. Limites do crescimento: um relatório para o projeto do Clube de Roma sobre o dilema da humanidade. São Paulo: Perspectivas, 1972.

OLIVEIRA, Michele. Assembleia de Bispos da Amazônia discute criação de pecado ecológico. Folha de São Paulo, São Paulo, 20 out. 2019, p. A18.

PAPA anuncia criação de Órgão para Amazônia no Vaticano. A Tarde, Salvador, 27 out. 2019, p. B5.

SÁ, Nelson de. Toda mídia. Folha de São Paulo, São Paulo, $1^{\circ}$ nov. 2019, p. A 24.

SINODO DOS BISPOS. ASSEMBLEIA ESPECIAL PARA A REGIÃO AMAZÔNICA - Amazônia: novos caminhos para a Igreja e para uma Ecologia Integral. Documento Final, Cidade do Vaticano, 26 out. 2019, 26p.

SPERB, Paula. Há 40 anos a ditadura proibiu líder de encontrar Papa no México. Folha de São Paulo, São Paulo, 21 out. 2019, p. A 14.

TAVARES, Ana Helena. Um bispo contra todas as crenças. A vida e as causas de Pedro Casaldaliga. Rio de Janeiro: Gramma, 2019.

VATICANO. Querida Amazônia. Exortação Apostólica Pós-Sinodal. Roma, 02 de fevereiro, 2020. Disponível em www.sinodoamazônico.va. Acesso em 03 abr. 2020.

\section{Dados do autor}

Joviniano S. de Carvalho Neto

Membro do CEAS desde 1968, professor de Ciência Política (aposentado) da UFBA onde continua ministrando a disciplina Igreja e Política, Doutor em Comunicação e Cultura Contemporâneas. E-mail: jovinianoneto@hotmail.com Lattes Id http://lattes.cnpq.br/2255490272129974 